\title{
HbAHP-25, a peptide designed in silico, exhibits potent anti-HIV activity in vitro
}

\author{
Tahir Bashir ${ }^{1}$, CS Kumar ${ }^{2}$, KVR Reddy $^{1 *}$ \\ From 2nd International Science Symposium on HIV and Infectious Diseases (HIV SCIENCE 2014) \\ Chennai, India. 30 January - 1 February 2014
}

\section{Background}

Identifying and / or designing molecules that can inhibit HIV infection and be safe to the host cells is highly desired.

\section{Methods}

HbAHP-25 was designed in silico against CD4 binding domain of gp120 of HIV-1 by molecular docking using $\mathrm{Z}$ dock and PROSA softwares. ELISA and SPR were used to determine the binding ability of HbAHP-25 to gp120. Anti-HIV activity of this peptide was checked by two different assays, viz: a) On TZM bl cells, using luciferase assay; b) On CEM-GFP cells and PBMCs using p24 antigen assay. MTT assay, TER/microsphere assay and Immunofluorescence were used to determine the effect of HbAHP-25 on cell viability, epithelial monolayer integrity and permeability.

\section{Results}

Five peptides were designed, and one of the peptides, HbAHP-25, exhibits significant anti-HIV activity against various strains of HIV-1, such as HIV-1 Ada, HIV-1 NL4-3, and HIV-1 IIIB. ELISA and SPR revealed a direct interaction between HbAHP-25 and gp120, thereby inhibiting its interaction with CD4 receptor. The peptide didn't affect cell viability even at higher concentrations; nor did it affect epithelial monolayer integrity or permeability. HbAHP- 25 also did not interfere with any tight junction proteins such as ZO-1 and Clauddin-1, thus maintaining cell integrity as well.

\section{Conclusion}

The peptide has potent anti-HIV activity, and can be explored as a potential therapeutic/prophylactic/preventive agent.

\section{Authors' details}

'Molecular Immunology \& Microbiology (MIM), National Institute for Research in Reproductive Health, Mumbai, India. ${ }^{2}$ Department of Bioinformatics, Dr. D.Y. Patil University CBD Belapur, Navi Mumbai, India.

Published: 27 May 2014

doi:10.1186/1471-2334-14-S3-E30

Cite this article as: Bashir et al:: HbAHP-25, a peptide designed in silico, exhibits potent anti-HIV activity in vitro. BMC Infectious Diseases 2014 14(Suppl 3):E30.

\footnotetext{
* Correspondence: reddyk@nirrh.res.in

'Molecular Immunology \& Microbiology (MIM), National Institute for

Research in Reproductive Health, Mumbai, India

Full list of author information is available at the end of the article
}

Submit your next manuscript to BioMed Central and take full advantage of:

- Convenient online submission

- Thorough peer review

- No space constraints or color figure charges

- Immediate publication on acceptance

- Inclusion in PubMed, CAS, Scopus and Google Scholar

- Research which is freely available for redistribution

Submit your manuscript at www.biomedcentral.com/submit
() Biomed Central 